\title{
Estrogen Receptors $\alpha$ and $\beta$ Differentially Regulate the Transcriptional Activity of the Urocortin Gene
}

\author{
Paola Haeger, ${ }^{1}$ María Estela Andrés, ${ }^{1}$ María Inés Forray, ${ }^{1,2}$ Claudia Daza, ${ }^{1}$ Silvia Araneda, ${ }^{3}$ and Katia Gysling ${ }^{1}$ \\ ${ }^{1}$ Department of Cellular and Molecular Biology, Faculty of Biological Sciences and ${ }^{2}$ Department of Pharmacy, Faculty of Chemistry, Catholic University of \\ Chile, 833-1010 Santiago, Chile, and '3nité Mixte de Recherche Centre National de la Recherche Scientifique 5123, Universite Claude Bernard Lyon I, 69622 \\ Villeurbanne Cedex, France
}

\begin{abstract}
Urocortin (Ucn), a highly conserved metazoan gene, is related to stress and feeding, behaviors with significant gender differences. We investigated whether estrogens regulate the expression of the Ucn gene using transient transfection in PC12 cells with the human Ucn (hUcn) promoter coupled to luciferase and either $\alpha$ or $\beta$ estrogen receptors (ER $\alpha$ or $\operatorname{ER} \beta$, respectively). The results demonstrate that estradiol $\left(\mathrm{E}_{2}\right)$ increases the activity of the hUcn promoter via $\mathrm{ER} \alpha$, and decreases $\mathrm{hU}$ cn promoter activity through $\mathrm{ER} \beta$. Deletions of the $\mathrm{hUcn}$ promoter show that the increase in promoter activity mediated by $\mathrm{E}_{2}-\mathrm{ER} \alpha$ depends on a promoter region containing a half-estrogen response element and an Sp1 site, and the decrease mediated by $\mathrm{E}_{2}$-ER $\beta$ depends on a proximal promoter region containing a cAMP response element. Ucn and ERs coexist in neurons of rat hypothalamic nuclei, giving anatomical support for a direct effect of estrogen receptors on the Ucn gene. By in situ hybridization, we observed that cycling female rats have a higher number of cells expressing Ucn mRNA than males in the paraventricular nucleus of the hypothalamus (PVN) and the septum. Both of these brain nuclei are related to stress behaviors and express moderate levels of Ucn. Furthermore, Ucn mRNA was significantly decreased in the PVN and increased in the septum $30 \mathrm{~d}$ after ovariectomy. Acute $\mathrm{E}_{2}$ administration to ovariectomized rats significantly increased Ucn mRNA expression in the $\mathrm{PVN}$ and septum. In conclusion, our in vitro and in vivo evidence suggests that estrogens exert a direct and differential transcriptional regulation of the Ucn gene.
\end{abstract}

Key words: estrogen; estradiol; stress; septum; gender differences; hypothalamus; CRH

\section{Introduction}

Urocortin (Ucn), a conserved metazoan peptide, has high affinity for both corticotropin releasing hormone (CRH) receptors, CRH-R1 and CRH-R2 (Vaughan et al., 1995, Donaldson et al., 1996). Selective CRH-R1 and CRH-R2 ligands are available; however, because Ucn and CRH share the same receptors, none of these available drugs allow discrimination between the physiologic actions of Ucn and CRH. Studies with CRH-deficient mice (CRH-KOs) have demonstrated that CRH is essential in the activation of the hypothalamic-pituitary-adrenal (HPA) axis by stress (Weninger et al., 1999). Male and female CRH-KOs have very low basal corticosterone levels, but respond disparately to stress (Muglia et al., 1995). Male CRH-KOs do not secrete corticosterone in response to stressful stimuli. In contrast, female CRH-KOs exhibit a substantial, although lower than normal, secretion of corticosterone in response to the same stressors. Thus,

Received March 12, 2005; revised March 27, 2006; accepted March 28, 2006.

This work was supported by Research Grants 1011017 from Fondo Nacional de Desarrollo Científico y Tecnológico de Chile and 2005/2P from Dirección de Investigación de la Pontificia Universidad Católica de Chile, and a cooperation program Evaluación-Orientación de la Cooperación Científica/Comisión Nacional de Investigación Científica y Tecnológica de Chile. We thank Drs. Ariadna Forray and Christopher Sankey for carefully reading and correcting this manuscript, and Lucy Chacoff for her assistance with different aspects of this work. We also thank Turner Biosystems for the donation of the Model 20E luminometer.

Correspondence should be addressed to Dr. Katia Gysling, Department of Cell and Molecular Biology, Faculty of Biological Sciences, Catholic University of Chile, 833-1010 Santiago, Chile. E-mail: kgysling@bio.puc.cl.

D01:10.1523/JNEUROSCI.0476-06.2006

Copyright $\odot 2006$ Society for Neuroscience $\quad$ 0270-6474/06/264908-09\$15.00/0
CRH-KOs suggest gender-specific differences on HPA axis control (Muglia et al., 2001). It is interesting to note, however, that $\mathrm{CRH}-\mathrm{KOs}$ conserve intact extrahypothalamic stress behaviors (Dunn and Swiergiel, 1999; Weninger et al., 1999). Furthermore, intracerebroventricular infusion of a specific CRH-R 1 antagonist (CP-154,526) inhibits shock-induced freezing response in $\mathrm{CRH}-\mathrm{KO}$ and wild-type mice, suggesting the activation of CRH-R1 but not CRH itself is necessary for this behavior. The role of Urocortin II and III in these CRH-R1-mediated behaviors is not pertinent because these peptides are selective agonists of CRH-R2 (for review, see Bale and Vale, 2004; Gysling et al., 2004). In addition to CRH, Ucn is the only known neuropeptide with a high affinity for CRH-R1; therefore, Ucn may be responsible for extrahypothalamic stress behaviors present in CRH-KOs.

Available evidence suggests that gender differences observed in the stress response are caused by estrogen regulation of CRH and CRH-binding protein expression (Miller et al., 2004; Van de Stolpe et al., 2004). Estrogens regulate transcription via a complex and highly regulated process. This process depends on the binding of estradiol $\left(\mathrm{E}_{2}\right)$ to estrogen receptor (ER) $\alpha$ and/or ER $\beta$, cellular contexts, and promoter sequences (Jones et al., 1999, Hall et al., 2001). Estrogens further regulate transcription via homodimers or heterodimers of $\mathrm{ER} \alpha, \mathrm{ER} \beta$, and consensus estrogen response elements (ERE). Transcription is also modulated by ER binding of specific elements [half-ERE, activated protein 1 (Ap1), cAMP response element (CRE), or specific protein $1(\mathrm{Sp} 1)]$ in- 
dependently or in specific associations (Porter et al., 1997; Sabbah et al., 1999; Shapiro et al., 2000; Martini and Katzenellenbogen, 2001, Petz et al., 2002, 2004; Sanchez et al., 2002; Schultz et al., 2005).

The similarity between Ucn and CRH genes and the potential physiologic role of Ucn in gender differences of the stress response led us to study whether estrogens regulate the transcription of the hUcn promoter. To this end, PC12 cells cotransfected with a reporter vector containing the $2.2 \mathrm{~kb}$ or deleted forms of the hUcn promoter and $\operatorname{ER} \alpha$ or $\operatorname{ER} \beta$ were exposed to $\mathrm{E}_{2}$ or tamoxifen. The effects of ovarian hormones on the in situ expression of Ucn mRNA in male and female brain rats during diestrus I, estrus, after ovariectomy (OVX), and $28 \mathrm{~h}$ after an injection of $\mathrm{E}_{2}$ to OVX rats were also studied.

\section{Materials and Methods}

Expression and reporter plasmids. The luciferase reporter construct pGL2hUS2 (graciously provided by Dr. Wylie W. Vale, The Clayton Foundation Laboratories for Peptide Biology, The Salk Institute, San Diego, CA) contains 2215 nucleotides of the hUcn promoter region plus 70 nucleotides of the exon1 (AF038633) (Zhao et al., 1998). The luciferase reporter vector pERE-TK-luc (gift from Dr. Valerie D. Clack, Duke University Medical School, Durham, NC) contains one copy of the consensus ERE. The expression vector pcDNA-ER $\alpha$ (gift from Dr. Pierre Chambon, University Louis Pasteur, Strasbourg, France) contains the cDNA of human $\mathrm{ER} \alpha$ and the expression vector pcDNA-ER $\beta$ (gift from Dr. Brigitte Fournier, Novartis Pharma AG, Basel, Switzerland) contains the cDNA of human $\mathrm{ER} \beta$. The expression vector pCGN-Sp1 contains the cDNA of human Sp1 (gift from Dr. Thomas Shenk, Princeton University, Princeton, NJ). Recombinant ER $\alpha$-Myc was generated by subcloning an NheI/ $X b a \mathrm{I} E R \alpha$ fragment (protein id: CAA27284, amino acids 1-378) in frame with Myc at the carboxyl end using the pcDNA3.1(-) Myc-HisB vector (Invitrogen, Carlsbad, CA).

Generation of deleted mutants of the $h U c n$ promoter. To obtain specific deleted mutants of the hUcn promoter, the pGL2-hUS2 construct was subjected to different digestions with pairs of specific restriction enzymes. The enzymes used were as follows: NheI/AatII for promoter $\Delta-161 /-41, N c o I / N h e I$ for promoter $\Delta-349 /-161, P s t \mathrm{I} / N c o$ I for promoter $\Delta-1229 /-349$, Mlu/PstI for promoter -427 , Mlu/NcoI for promoter -349 , and Mlu/NheI for promoter -161 . The digestion products were subjected to electrophoresis and the higher molecular weight product was purified with the Rapid Gel Extraction kit (Qiagen, Valencia, CA). Purified fragments were subjected to pfu polymerase and ligated with ligase T4. Plasmids were purified with minipreps and maxipreps (Qiagen; Bio-Rad, Hercules, CA). Correct assembles were confirmed by sequencing. All transfection studies were repeated with DNA obtained from at least three independent plasmid preparations.

PC12 cell culture and transient transfection. PC12 rat pheochromocytoma cells were maintained in DMEM supplemented with $10 \%$ horse serum (HS) and $5 \%$ fetal bovine serum (Invitrogen), $100 \mathrm{IU} / \mathrm{ml}$ penicillin, and $100 \mu \mathrm{g} / \mathrm{ml}$ streptomycin at $37^{\circ} \mathrm{C}$ in a humidified incubator in $10 \% \mathrm{CO}_{2}$. PC12 cells were transfected with lipofectamine 2000 reagent (Invitrogen). Briefly, cells were plated at a density of $\sim 2.5 \times 10^{5}$ cells in 24 -well plates and transfected the next day with $0.75 \mu \mathrm{g}$ of pGL2-hUS2 and the same molar amount of pcDNA-ER $\alpha$ or $-\mathrm{ER} \beta$, and $5 \mathrm{ng}$ of pRLSV40. In the case that two expression vectors were cotransfected, the amounts transfected were as follows: $0.5 \mu \mathrm{g}$ of pGL2-hUS2 and $0.35 \mu \mathrm{g}$ of pcDNA-ER $\alpha$, and from 0.15 to $0.75 \mu \mathrm{g}$ of pcDNA-ER $\beta$ or pCGN-Sp1. Final DNA amounts were achieved by adjusting with pBluescript.

Before transfection, media were replaced with phenol red-free media supplemented with $10 \%$ charcoal-stripped HS and 5\% charcoal-stripped FBS, and cells were allowed to recover overnight. Cells were treated with 10 nм 17- $\beta$ estradiol (Sigma, St. Louis, MO), 1000 nм tamoxifen (Sigma), 0.5 mM 8-bromo-cAMP (8-Br-cAMP), or vehicle (ethanol or DMSO) for $24 \mathrm{~h}$ and harvested in $100 \mu \mathrm{l}$ of passive lysis buffer (Promega, Madison, WI). Light units were determined by a Dual Luciferase Reporter Assay System (Promega). Pilot experiments with different con- centrations of the reporter vector and different times after adding the substrate were used to select the appropriate conditions to work in the linear range of the assay. Briefly, each cell extract was mixed with luciferase assay reagent and firefly luciferase light units were read for 10 s/sample on a luminometer (Model 20E; Turner Biosystems, Sunnyvale, CA). Firefly luciferase activity corresponds to the light units of firefly luciferase normalized to light units of renilla luciferase or to total protein.

Electrophoretic mobility shift assay. A $50 \mathrm{bp} \mathrm{hUcn} \mathrm{promoter} \mathrm{probe} \mathrm{con-}$ taining the proximal half-ERE and the medial Sp1 site, named "half-ERE/ Sp1," was end-labeled using T4-polynucleotide kinase and $\left[\gamma^{32} \mathrm{P}\right] \mathrm{ATP}$. PC12 cells were transfected with $5 \mu \mathrm{g}$ of pcDNA-ER $\alpha$ or recombinant pcDNA-ER $\alpha$-Myc and, $48 \mathrm{~h}$ after transfection, a nuclear extract was prepared. Six hours before preparing the nuclear extract, the transfected cells were treated with $10 \mathrm{nM} \mathrm{E}_{2}$. Briefly, $10 \mu \mathrm{g}$ of the nuclear extract was incubated in electrophoretic mobility shift assay (EMSA) binding buffer with or without $350 \times$ cold probe or $2 \mu \mathrm{g}$ of anti-Sp1 or anti-Myc (Santa Cruz Biotechnology, Santa Cruz, CA), or rabbit IgG for $30 \mathrm{~min}$ on ice, and $15 \mathrm{~min}$ at room temperature, consecutively. After the addition of $\left[{ }^{32} \mathrm{P}\right]$-labeled half-ERE/Sp1, the mixture was incubated for $15 \mathrm{~min}$ at room temperature. Electrophoresis was performed in $4 \%$ polyacrylamide gels and with $0.5 \times$ Tris-borate EDTA buffer at $250 \mathrm{~V}$. Radioactive bands were visualized by autoradiography.

Experimental animals. Female and male Sprague Dawley rats weighing 200-300 g were used. Rats were maintained on a 14/10 h light/dark schedule (lights on between 7:00 A.M. and 9:00 P.M.) and food and water were available ad libitum. The stages of the estrous cycle in female rats were assessed by vaginal smear examination and only animals presenting at least four $4 \mathrm{~d}$ consecutive cycles were used. Female rats during diestrus I and estrus were selected for the present study. All experiments were conducted in accordance with institutional and international guidelines [National Institutes of Health (NIH) Guide for the Care and Use of Laboratory Animals].

A group of female rats (200-240 g) was bilaterally ovariectomized under deep chloral hydrate anesthesia (400 $\mathrm{mg} / \mathrm{kg}$ body weight, i.p.). Thirty days after ovariectomy (OVX-30), rats weighed 270-320 g and were injected intramuscularly at 11:00 A.M. with $\mathrm{E}_{2}$ (benzoate salt; 10 $\mu \mathrm{g} / \mathrm{kg}$ in corn oil) or with vehicle (corn oil) and killed $28 \mathrm{~h}$ later. Twenty eight $\mathrm{h}$ after the $\mathrm{E}_{2}$ injection to a parallel group of OVX rats, $\mathrm{E}_{2}$ plasma levels were $57.3 \pm 9.1 \mathrm{pg} / \mathrm{ml}(n=3)$. In situ hybridization (ISH) experiments were conducted in the following experimental groups: male, female rats during diestrus I and estrus, and OVX-30 rats, $28 \mathrm{~h}$ after a single injection of $\mathrm{E}_{2}$ or vehicle.

Brain tissue fixation. The rats were deeply anesthetized with chloral hydrate anesthesia ( $400 \mathrm{mg} / \mathrm{kg}$ body weight, i.p.) and perfused transcardially with physiological saline followed by $3 \%$ paraformaldehyde in 0.1 $\mathrm{M}$ phosphate buffer (PB), $\mathrm{pH}$ 7.4. Thereafter, brains were postfixed in the same fixative solution for $30 \mathrm{~min}$ and thereafter transferred to $20 \% \mathrm{su}-$ crose in $0.1 \mathrm{M}$ PB for $48 \mathrm{~h}$. Finally, brains were sectioned into coronal slices by means of a vibratome (Vibratome 3000; Technical Products International, St Louis, MO).

Nonisotopic in situ hybridization and immunohistochemistry. Nonisotopic ISH was performed essentially as described previously (Andres et al., 1996). Briefly, deoxynucleotide probes U1 (5'-tcacttgcccaccgaatcgaatatgatgcggttctgctc- $\left.3^{\prime}\right)$, complementary to nucleotides $388-426$, and U2 (5'-tcacttgcccaccgaatcgaa- $\left.3^{\prime}\right)$, complementary to nucleotides 406426 of the Ucn mRNA (NM_019150), were used for the ISH experiments. Both probes were $3^{\prime}$ end-labeled with terminal transferase and dATP/digoxigenin-labeled deoxyuridine-triphosphate (9/1). Thirty micrometer coronal slices were hybridized overnight at $38^{\circ} \mathrm{C}$ for $\mathrm{U} 1$ and at $28^{\circ} \mathrm{C}$ for $\mathrm{U} 2$ in the presence of $10 \mathrm{pmol} / \mathrm{ml}$ of $\mathrm{U} 1$ digoxigenin (DIG)labeled probe. After hybridization, tissue slices were rinsed twice with $2 \times$ SSC and one time in $1 \times$ SSC for 10 min each at $42^{\circ} \mathrm{C}$. For control, similar coronal sections were hybridized in the presence of (1) U1 or U2 DIGlabeled probe plus $100 \times$ nonlabeled U1 or U2 probe and (2) DIG-labeled scrambled probes with the same nucleotides of U1 or U2 in a random sequence. Only background staining was observed in both controls. The presence of DIG-labeling in brain tissue sections was detected with antiDIG antibodies conjugated to alkaline phosphatase (Boehringer Mannheim GmbH Biochemica, Mannheim, Germany) and using nitroblue 
tetrazolium and 5-bromo-4-chloro-3-indolyl phosphate (Invitrogen) as enzyme substrates. In some cases, immunohistochemistry (IHC) for $\mathrm{ER} \alpha$ or $\mathrm{ER} \beta$ was performed after the ISH protocol. For this purpose, at the end of the ISH protocol, the tissue sections were incubated with $1 / 250$ ER $\beta$ antibody (H150; Santa Cruz Biotechnology) and developed with the $\mathrm{ABC}$ system (Vector Laboratories, Burlingame, $\mathrm{CA}$ ). The sections were mounted on glass slides with gelatin $(0.1 \%)$, dried overnight, coverslipped, and observed under light microscopy. Confocal double immunofluorescence was used to study the coexistence of Ucn with ER $\alpha$. For this purpose, $20 \mu \mathrm{m}$ coronal slices were obtained from rats injected with colchicine $(100 \mu \mathrm{g}) 48 \mathrm{~h}$ before killing. After a $1 \mathrm{~h}$ preincubation in $1 \%$ bovine serum albumin, $0.5 \%$ Triton X-100, and $0.02 \%$ Sodium Azide in PBS, sections were incubated over night at room temperature simultaneously with 1/1000 of Ucn antibody (R20; Santa Cruz Biotechnology) and 1/250 ER- $\alpha$ antibody (H184; Santa Cruz Biotechnology). Sections were then rinsed with PBS and incubated with secondary FITC anti-goat and Cy3 anti-rabbit IgG (1/100) at room temperature for $4 \mathrm{~h}$ in a PBS buffer containing $0.2 \%$ gelatin and $0.1 \%$ Triton $\mathrm{X}-100$. The sections were rinsed in PBS and mounted with glycerol. Immunofluorescence was analyzed by confocal microscopy. Controls for the immunofluorescence reaction were performed with $\mathrm{Ucn}$ antibody preadsorbed with blocking peptide, and without first or second antibodies. All these controls yielded only background staining.

In vivo data analysis. ISH experiments were evaluated using a Nikon (Melville, NY) Labophot-2 microscope equipped with a color video camera (CCD-IRIS; Sony, Tokyo, Japan) coupled to a computer (Power Macintosh 7600/132; Apple, Cupertino, CA). Positive DIG-labeled cells in the dorsolateral septum (DLS) were counted in coronal sections, at a rostrocaudal level of $0.2 \mathrm{~mm}$ from bregma (Paxinos and Watson, 1986). In the case of the paraventricular nucleus of the hypothalamus (PVN), positive DIG-labeled cells were counted in coronal sections at the rostrocaudal level of $-1.80 \mathrm{~mm}$ from bregma. Cells with alkaline phosphatase reaction product originated from DIG-labeled probes were counted in sample areas of $0.17 \mathrm{~mm}^{2}$ for DLS and $0.29 \mathrm{~mm}^{2}$ for PVN, using the NIH 1.61 Image/ppc program (Andres et al., 1996). In each experimental animal, 2-3 slices at the same rostrocaudal level were used to examine the number of DIG-labeled cells in each area studied. Data are presented as the number of DIG-labeled cells $/ \mathrm{mm}^{2}$; each value corresponds to the mean \pm SEM of three to seven independent experiments.

To evaluate the percentage of Ucn mRNA and ER $\beta$ coexpression in the parvicellular region of the PVN, tissue sections were analyzed using an Olympus (Melville, NY) microscope and images were captured with an Olympus Camedia digital camera. Tissue sections at the level of the PVN were selected for analysis. The total number of ER $\beta$-like labeled cells was manually counted in the parvicellular region of the PVN. The percentage of colocalization was determined by counting the number of cells presenting both brown nuclear ER $\beta$-like and blue cytoplasmatic Ucn mRNA labeling.

Statistics. Statistical significance for ISH and transfection experiments was assessed by one-way ANOVA followed by Newman-Keuls multiple comparison post hoc test using the GraphPad Software (San Diego, CA), Prism version 3.0. Luciferase activity and relative luciferase activity after $\mathrm{E}_{2}$ or tamoxifen treatments were compared against their respective vehicles. Absolute luciferase values were analyzed by one-way ANOVA followed by Newman-Keuls and relative luciferase values by one-way ANOVA followed by Dunn post hoc test.

\section{Results}

\section{Activity of the hUcn promoter cotransfected with ER $\alpha$ and/or $\operatorname{ER} \beta$}

To evaluate whether ERs directly regulate the transcriptional activity of the hUcn promoter, PC12 cells were transiently cotransfected with pGL2-hUS2 and pcDNA-ER $\alpha$, and/or pcDNA-ER $\beta$. The transcriptional activity of pGL2-hUS2 was significantly increased by overexpressing ER $\beta$ and to a lesser extent with ER $\alpha$ (Fig. 1 A). The treatment of transfected PC12 cells with $\mathrm{E}_{2}(10 \mathrm{~nm})$ and tamoxifen $(1000 \mathrm{nM})$ significantly increased the transcriptional activity of the hUcn promoter when $\mathrm{ER} \alpha$ was overex-
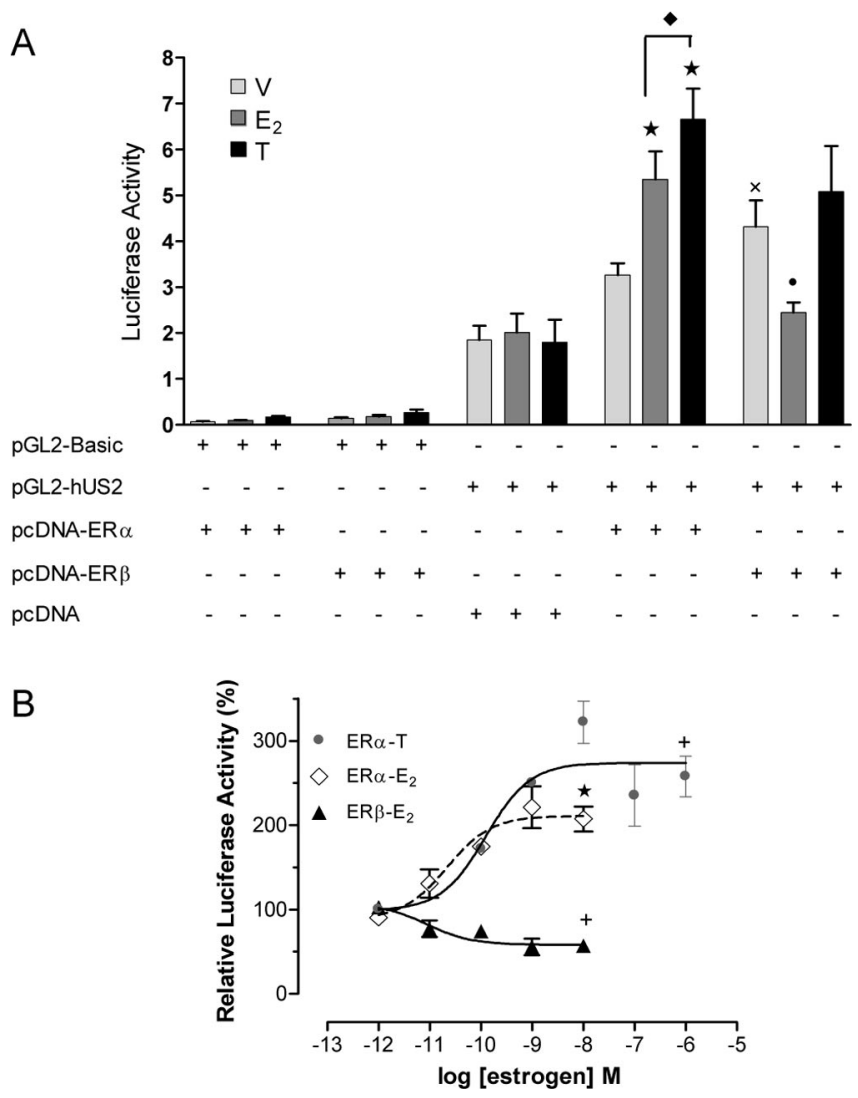

Figure 1. Activation of $E R \alpha$ increases and activation of $E R \beta$ decreases the activity of the hUcn promoter. $A$, Effect of $\mathrm{E}_{2}$ and tamoxifen (T) on the activity of the hUcn promoter through $\operatorname{ER} \alpha$ (pCDNA-ER $\alpha$ ) or $E R \beta$ (pcDNA-ER $\beta$ ) or when cotransfected with the empty vector (pcDNA). Luciferase activity corresponds to light units of firefly luciferase quantified $24 \mathrm{~h}$ after cells were treated with $10 \mathrm{~nm}_{2}, 1000 \mathrm{~nm} \mathrm{~T}$, or vehicle (V; ethanol) and normalized to renilla luciferase light units. $B$, Dose-response effect of $E_{2}$ and $T$ through $E R \alpha$ and of $E_{2}$ through $E R \beta$, on the activity of the hUcn promoter. Relative luciferase activity corresponds to the luciferase activity relative to vehicle (100\%). Values are the mean \pm SEM of three independent experiments. Statistical analysis by ANOVA followed by Newman-Keuls $(\boldsymbol{A})$ or Dunn $(\boldsymbol{B})$ post hoc tests gave the following significances: $\star, p<0.001, \mathbf{+}, p<0.01$, and,$p<0.05$, compared with respective vehicle control; $\times, p<0.01$, compared with $p$ CDNA/pGL2-hUS2; $\bullet, p<0.05$, compared between them.

pressed in PC12 cells (Fig. 1A). The effects of $\mathrm{E}_{2}$ and tamoxifen were also found to be dose-dependent (Fig. $1 B$ ). The presence of $\mathrm{E}_{2}$ significantly inhibited the transcriptional activity of the hUcn promoter induced by the overexpression of ER $\beta$ in PC12 cells (Fig. $1 A$ ). This effect of $\mathrm{E}_{2}$ mediated by $\mathrm{ER} \beta$ was dose-dependent (Fig. $1 B$ ) and was also observed with 10 -fold lower pcDNA-ER $\beta$, discarding a nonspecific squelching of essential transcriptional activators (data not shown). The transcriptional activity of the hUcn promoter in the presence of $\operatorname{ER} \beta$ was not affected by the treatment with tamoxifen. Because $\mathrm{E}_{2}$ exerted opposite effects on the basis of each ER, we also tested the effect of cotransfecting both ERs together with the hUcn promoter. $\mathrm{E}_{2}$ and tamoxifen were found to increase the transcriptional activity of the hUcn promoter to a similar extent when $\operatorname{ER} \alpha$ alone or both ERs were cotransfected (data no shown).

To test the specificity of the observed effects, PC12 cells were transiently cotransfected with pGL2-hUS2 and pcDNA, the empty expression vector for both $\mathrm{ER} \alpha$ and $\mathrm{ER} \beta$. In both controls, the basal transcriptional activity of pGL2-hUS2 was not modified by estrogen (Fig. $1 A$ ). PC12 cells do not express detectable levels of $\operatorname{ER} \beta$, but they do express low levels of $\operatorname{ER} \alpha$ (data not shown). 


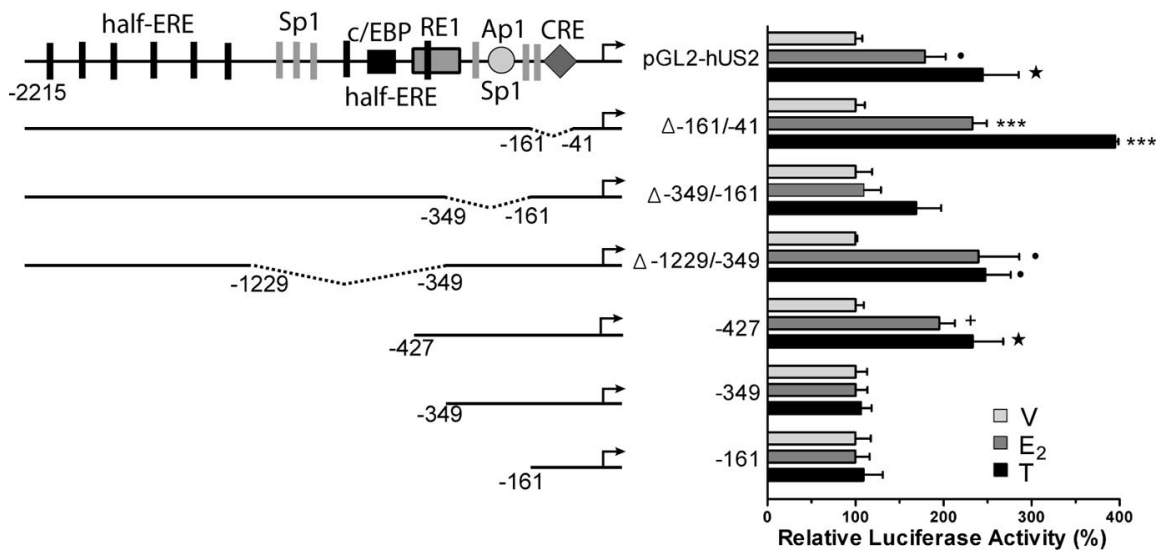

Figure 2. Activation of $E R \alpha$ by $E_{2}$ and $T$ increases the activity of the hUcn promoter through a promoter region containing half-ERE, Sp1, and Ap1 sites. PC12 cells were cotransfected with the hUcn promoter (pGL2-hUS2) or deleted mutants and pcDNA$\mathrm{ER} \alpha$. The results are expressed relative to vehicle (100\%). Luciferase activity corresponds to light units of firefly luciferase normalized to renilla luciferase light units. Values are the mean \pm SEM of two to three independent experiments. Statistical analysis by ANOVA followed by Dunn post hoc test gave the following significances: $\star, p<0.001 ; \boldsymbol{+}, p<0.01$; and $p<0.05$, compared with respective vehicle control. Analysis by Mann-Whitney $U$ test gave the following significance: $\star \star \star, p<0.001$, compared with respective vehicle control.

This suggests that the endogenous expression of ER $\alpha$ in PC12 is not sufficient to induce the hUcn promoter (Fig. $1 A$ ). As an additional control, cells were transiently cotransfected with the promoterless vector (pGL2-Basic) and $\mathrm{pcDNA}-\mathrm{ER} \alpha$ or ER $\beta$ and treated with $\mathrm{E}_{2}$ or tamoxifen, as above. In this case, no significant transcriptional activity was observed, confirming the specificity of the hUcn promoter response (Fig. $1 A$ ). As a positive control, the effect of E2 on the transcriptional activity of a consensus ERE was studied. $\mathrm{E}_{2}$, but not tamoxifen, significantly increased $\mathrm{ER} \alpha$ and ER $\beta$-mediated transcriptional activity of pERE-TK-luc (data not shown). Interestingly, $\mathrm{E}_{2}$ and $\mathrm{ER} \alpha$ induced a similar increase of the transcriptional activity of the hUcn promoter and the consensus ERE.

\section{Analysis of the hUcn promoter}

The different mammalian Ucn promoters cloned today are highly homologous and share common transcription factor response elements, suggesting conserved functional roles (Zhao et al., 1998). The hUcn promoter does not have a consensus ERE. However, a screening of the hUcn promoter with the Transcription Search Software (TESS; http://www.cbil.upenn.edu/cgi-bin/tess/ tess) demonstrated the presence of eight half-palindromic EREs in positions $-2065,-1606,-1594,-1540,-1402,-896$, -779 , and -353 of the hUcn promoter. In addition, other response elements associated with estrogen receptors such as Ap1, CRE, and CCAAT/enhancer-binding protein elements (Zhao et al., 1998) are also present. The analysis also showed three groups of Sp1 sites, hereafter referred to as proximal (two sites), medial (one site), and distal (three sites) to the transcription initiation site (for schema, see Fig. 2). The hUcn promoter also contains a repressor element 1 (RE1)-like sequence. The sequence of the PGL2-Basic (promoterless) vector was also found to have Ap1like and Sp1 sites, but not half-ERE.

\section{Region of the hUcn promoter responsible for the effect of estrogens through $\mathrm{ER} \alpha$}

To investigate which region of the hUcn promoter was responsible for the stimulatory effect of $\mathrm{E}_{2}$ mediated by $\mathrm{ER} \alpha$, a series of deletions of the hUcn promoter were performed. The pGL2hUS2 and six different deletion mutants were transfected into
PC12 cells (Fig. 2). Only the $\Delta-161 /-41$ promoter presented a significantly lower basal activity compared with pGL2-hUS2 $(0.9 \pm 0.1$ compared with $3.5 \pm 0.3$ luciferase activity; $p<0.001)$. The $\Delta-161 /-41$ promoter lacks the CRE and one of the proximal Sp1 sites. Therefore, the decrease in basal activity observed with this promoter indicates that CRE, Sp1, or both elements are essential for basal transcription of the hUcn.

PC12 cells cotransfected with pGL2hUS2 or the six different deletion mutants plus $\mathrm{ER} \alpha$ were treated with $\mathrm{E}_{2}$ and tamoxifen. The activity of the hUcn, $\Delta-161 /-41$, $\Delta-1229 /-349$, and -427 promoters was significantly increased after $\mathrm{E}_{2}$ or tamoxifen treatment (Fig. 2). In contrast, the activity of the $\Delta-349 /-161,-349$, and -161 promoters was not affected by $\mathrm{E}_{2}$ or tamoxifen treatment (Fig. 2). Thus, the deletion of either the proximal half-ERE $(-349)$ or the segment containing the medial Sp1 and Ap1 elements $(\Delta-349 /-161)$ completely attenuated the effect of $\mathrm{E}_{2}$ and tamoxifen treatments. Furthermore, the $\Delta-1229 /-349$ promoter in which a distal half-ERE approaches the segment containing the medial Sp1 and Ap1 elements conserved the response to $\mathrm{E}_{2}$ and tamoxifen. This suggests that the distal half-ERE substitutes the proximal deleted half-ERE, or that the other element becomes functional. The results also indicate that the -427 promoter is the minimum promoter necessary to observe $\mathrm{E}_{2^{-}}$and tamoxifen-induced increases of hUcn promoter activity. Finally, the $\Delta-161 /-41$ promoter (which demonstrated very low basal activity), conserved the response to $\mathrm{E}_{2}$ and tamoxifen treatments. This provides further evidence that the promoter region containing the proximal half-ERE and medial Sp1 and/or Apl elements are necessary and sufficient for the ER $\alpha$-dependent increase of $\mathrm{hUcn}$ promoter activity induced by $\mathrm{E}_{2}$ and tamoxifen.

\section{Spl overexpression and transcriptional activity of the hUcn promoter}

To analyze the contribution of Sp1 to the activity of the hUcn promoter, PC12 cells were cotransfected with pGL2-hUS2 or deleted mutants of the hUcn promoter and pCGN-Sp1. The transcriptional activity in each condition was compared with the activity of the empty pCGN vector. Overexpression of Sp1 was found to significantly increase the activity of pGL2-hUS2. Because the $\Delta-349 /-161$ mutant also shows a significant activation by $S p 1$, together with the fact that the -427 mutant shows a lower activation by $S p 1$, it is possible to suggest that distal Sp1 sites play a significant role in mediating hUcn promoter activation. The further deletion of 77 nucleotides generating the -349 mutant induced a significantly higher Sp1 activation, suggesting that the medial and proximal sites are relevant to Spl transactivation. Moreover, the deletion of these 77 nucleotides eliminates the RE1 repressor element, providing further evidence that the medial and/or proximal Sp1 sites are under RE1-dependent repression.

\section{Sp1 overexpression and the effect of $E_{2}$ mediated by ER $\alpha$}

It has been shown previously that the ER $\alpha$ transactivation of several genes requires a configuration of Sp1 $(\mathrm{N})_{\mathrm{x}}$ half-ERE of DNA elements (for review, see Sanchez et al., 2002). To study whether Sp1 and ER $\alpha$ converge in the activation of the hUcn 


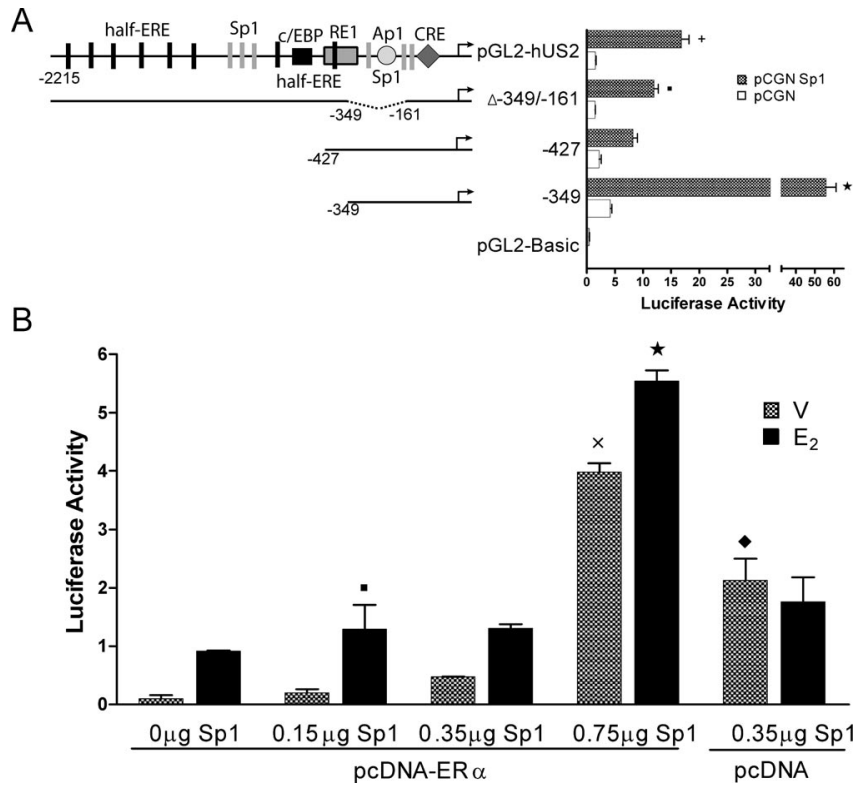

Figure 3. Sp1 overexpression increases the activity of the Ucn promoter. $A, P C 12$ cells were cotransfected with pGL2-hUS2 or deleted mutants of the hUcn promoter, or the empty reporter vector (pGL2-Basic) $(0.75 \mu \mathrm{g})$, and the Sp1 expression vector (Sp1) or the respective empty vector (pCGN) $(0.8 \mu \mathrm{g})$. Luciferase activity of pGL2-Basic plus pCGN was $0.081 \pm 0.006$ and of pGL2-Basic plus Sp1 was $0.406 \pm 0.059$. B, PC12 cells were cotransfected with pGL2-hUS2 (0.5 $\mu \mathrm{g})$ and $\mathrm{Sp} 1$ and $\mathrm{pcDNA}-\mathrm{ER} \alpha(0.35 \mu \mathrm{g})$ expression vectors. PC12 cells were cotransfected with PGL2-hUS2 and pCDNA-ER $\alpha$ and increasing amounts of Sp1 expression vector $(0.15,0.35$, and $0.75 \mu \mathrm{g}$ ). Transfected cells were treated for $24 \mathrm{~h}$ with $10 \mathrm{~nm}_{2}$ or vehicle (V; ethanol). Luciferase activity corresponds to light units of firefly luciferase normalized to total protein. Statistical analysis by ANOVA followed by Newman-Keuls post hoc test gave the following significances: (in $\boldsymbol{A}$ ) $\star, p<0.001, \boldsymbol{\mathbf { }}, p<0.01$, and $\boldsymbol{\square}, p<0.05$ compared with the empty vector; (in $\boldsymbol{B}$ ) $\star, p<0.001$ and $\boldsymbol{\square}, p<0.05$ compared with respective vehicle control; $\times, p<0.001$, compared with 0.15 and $0.35 \mu \mathrm{gSp} 1 / \mathrm{pcDNA}$-ER $\alpha$ treated to vehicle; $\diamond, p<0.01$, compared with 0.35 Sp1/pCDNA-ER $\alpha$.

promoter, PC12 cells were cotransfected with pGL2-hUS2 and $0.35 \mu \mathrm{g}$ of pcDNA-ER $\alpha$, with increasing concentrations of pCGN-Sp1. As depicted in Figure $3 B$, the activity of the hUcn promoter increased concomitantly with the concentration of Sp1. In addition, significant decreases were found in the activity of the hUcn promoter by Sp1 in the presence of ER $\alpha$ (compare $0.35 \mu \mathrm{g}$ of Sp1/pcDNA and $0.35 \mu \mathrm{g}$ of $\mathrm{Sp} 1 / \mathrm{pcDNA}-\mathrm{ER} \alpha$ ). This suggests an antagonistic effect of ER $\alpha$ on the hUcn promoter that is independent of $\mathrm{E}_{2}$. Incubation with $10 \mathrm{nM} \mathrm{E}_{2}$ significantly increased the activity of the pGL2-hUS2 in all the Sp1-transfected concentrations (see Fig. 5B), indicating that the effects of $\mathrm{Sp} 1$ and $\mathrm{E}_{2}-\mathrm{ER} \alpha$ are additive. The incubation with $10 \mathrm{nM} \mathrm{E}_{2}$ for $24 \mathrm{~h}$ did not affect basal activity obtained after transfection with only 0.35 $\mu \mathrm{g}$ of pCGN-Sp1. The presence of pCGN did not change basal activity of the pGL2-hUS2 and the $\mathrm{E}_{2}$ effect mediated by ER $\alpha$ (Fig. 3B).

\section{Binding of Sp1 over the Sp1 medial site}

The binding of ER $\alpha$ and $\mathrm{Sp} 1$ to the hUcn promoter was studied by EMSA using a 50 bp probe containing the proximal half-ERE and the medial Sp1 site (half-ERE/Sp1 Ucn probe) (Fig. 4). Two major retarded complexes (C1 and C2) (Fig. 4) were visualized when $10 \mu \mathrm{g}$ of nuclear extracts of PC12 cells transfected with $5 \mu \mathrm{g}$ of pcDNA-ER $\alpha$ were incubated with labeled half-ERE/Sp1 Ucn probe (Fig. $4 A$, lane 1 ). Competition with $350 \times$ excess of unlabeled probe prevented the formation of both complexes (Fig. $4 A$, lane 2), confirming the specificity of the complexes formed. To
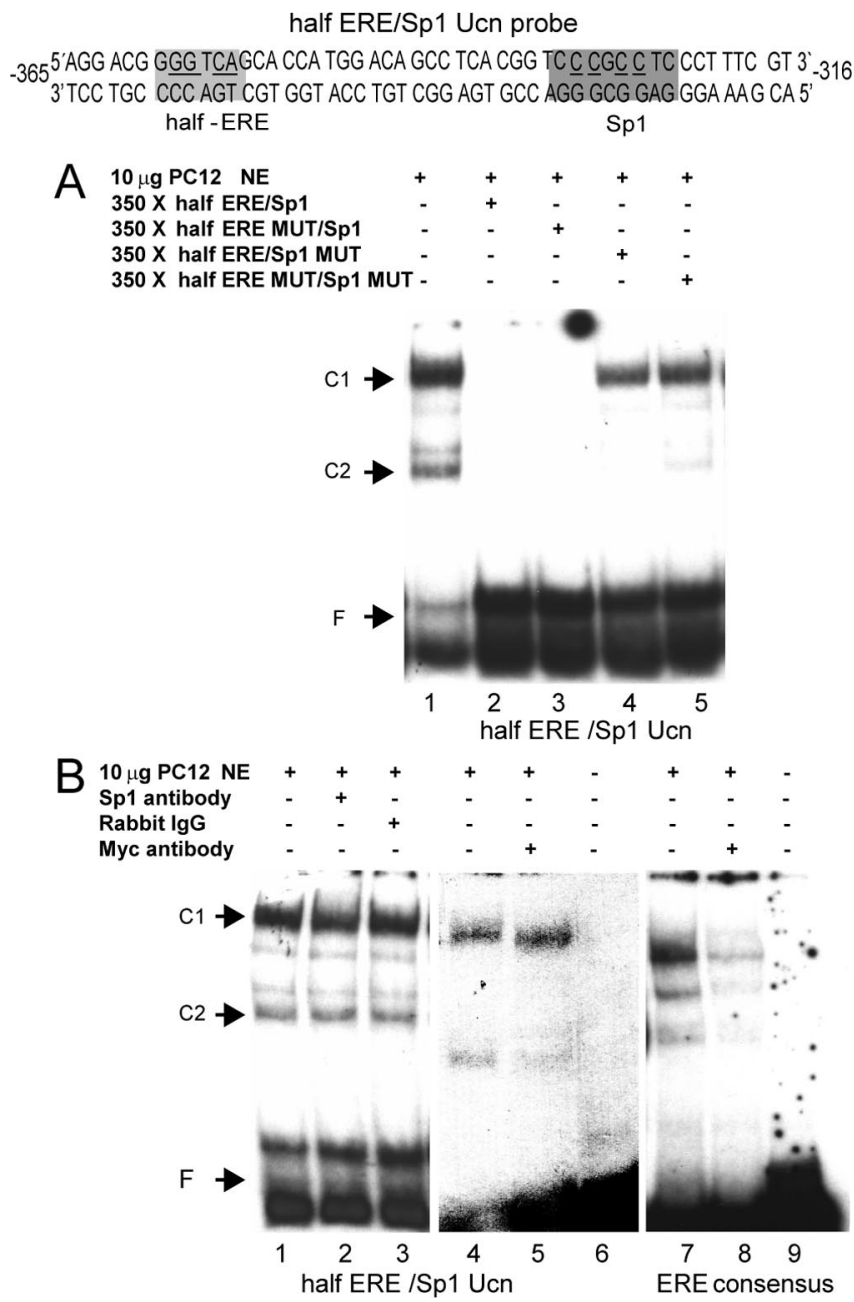

Figure 4. EMSA with PC12 nuclear extracts. A radiolabeled probe corresponding to the hUcn promoter containing the most proximal half-ERE and medial Sp1 site (halfERE/Sp1 Ucn probe) was used in a gel mobility assay. Ten micrograms of a nuclear extract of $\mathrm{PC} 12$ cells transfected with pcDNAER $\alpha(\boldsymbol{A}, \boldsymbol{B}$, left) or with pcDNAER $\alpha$-Myc ( $\boldsymbol{B}$, middle and right) was incubated in the different conditions depicted in the figure. $C 1$ and $C 2$ correspond to two retarded DNA/protein complexes. F corresponds to the free probe. Results in $\boldsymbol{A}$ and $\boldsymbol{B}$ are representative of three and two independent experiments, respectively.

further learn the composition of the complexes, competition with three different mutated probes was performed (underlined nucleotides in the probe sequence of Fig. 4 were changed to thymine). Competition with $350 \times$ excess of cold half-ERE mutant (MUT)/Sp1 abolished both complexes (Fig. 4A, lane 3). However, competition with $350 \times$ excess of cold half-ERE/Sp1 MUT abolished only the C2 complex (Fig. 4A, lane 4), indicating that the $\mathrm{C} 1$ complex is dependent on the integrity of the Sp1 site. Competition with $350 \times$ excess of cold half-ERE MUT/Sp1 MUT decreased the intensity of the $\mathrm{C} 2$ complex (Fig. $4 A$, lane 5), suggesting that the $\mathrm{C} 2$ complex depends on other unknown elements and/or protein interactions. These preliminary results suggest that the formation of the $\mathrm{C} 2$ complex is also dependent on the integrity of the half-ERE and Sp1 site.

A specific Sp1 antibody was used to further study the role of the $\mathrm{Sp} 1$ in complex formation. Incubation with the Sp1 antibody decreased the intensity of the $\mathrm{C} 1$ complex by $23 \%$ but did not super-shift the same complex (Fig. $4 B$, compare lanes 1,2). In contrast, the incubation with an unrelated antibody did not affect the intensity of the complexes (Fig. $4 B$, compare lanes 1, 3). 


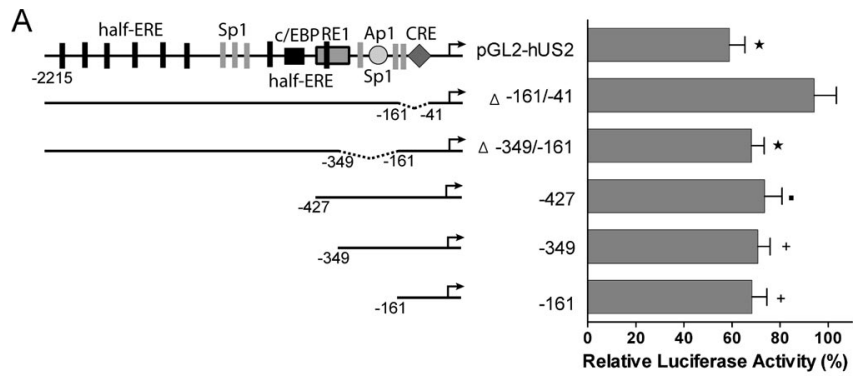

B

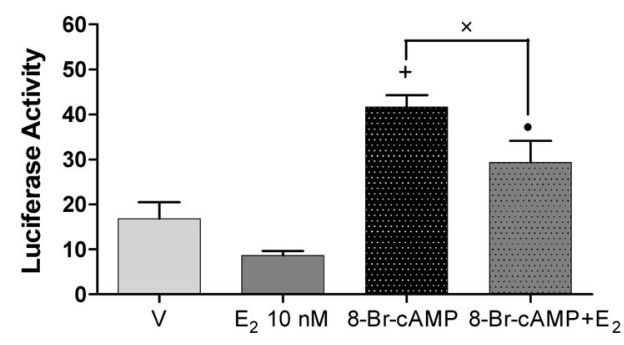

Figure 5. Activation of $E R \beta$ by $E_{2}$ represses the activity of the hUcn promoter through the region containing a CRE site. A, PC12 cells were cotransfected with PGL2-hUS2 or deleted mutants of the hUcn promoter and $\mathrm{pCDNA}-\mathrm{ER} \beta$. The results are expressed relative to vehicle (100\%). Luciferase activity corresponds to light units of firefly luciferase normalized to renilla luciferase light units. $\boldsymbol{B}, \mathrm{PC} 12$ cells were cotransfected with the -161 promoter and pcDNAER $\beta$ and treated for $24 \mathrm{~h}$ with $10 \mathrm{~nm}_{2}$ and/or $0.5 \mathrm{~mm}$ 8-Br-cAMP. Vehicle $(\mathrm{V})$ in $\boldsymbol{B}$ corresponds to ethanol plus DMSO used to $E_{2}$ and 8 -Br-cAMP, respectively. All of the treatment conditions have the same concentration of each vehicle. Luciferase activity corresponds to light units of firefly luciferase normalized to total protein. Values are the mean \pm SEM of two to three independent experiments. Statistical analysis by ANOVA followed by Dunn post hoc test gave the following significances: $\star, p<0.001, \mathbf{+}, p<0.01$, and $\mathbf{0}, p<0.05$, compared with respective vehicle control; $\times, p<0.05$, compared between them.

Together, the results indicate that the Sp1 site is necessary for the $\mathrm{C} 1$ complex formation and suggest that the Sp1 protein is also part of this complex. This does not discount the binding of other Sp proteins in the complex. To learn whether ER $\alpha$ is involved in the retarded complexes, a nuclear extract of PC12 cells transfected with the $5 \mu \mathrm{g}$ pcDNA-ER $\alpha$-Myc protein was incubated with either the same half-ERE/Sp1 Ucn probe (Fig. $4 B$, middle) or with an ERE consensus probe (Fig. $4 B$, right). The incubation with the Myc antibody (Fig. $4 B$, lane 5) decreased the intensity of the $\mathrm{C} 2$ complex by $68 \%$, indicating that $\mathrm{ER} \alpha$ is part of this complex. The control with the consensus ERE-labeled probe yielded three retarded complexes (Fig. $4 B$, lane 7 ) that were significantly reduced in the presence of the Myc antibody (Fig. 4B, lane 8). This indicates that the recombinant ER $\alpha$-Myc protein binds to ERE. Incubation of each labeled probe in the absence of PC12 nuclear extract did not show any retarded complexes (Fig. $4 B$, lanes 6,9$)$. Together, these preliminary results suggest that the half-ERE and Sp1 site are necessary for C2 complex formation, and that $\mathrm{ER} \alpha$ is part of this complex.

\section{Region of the hUcn promoter responsible for the effect of estrogens through $\mathrm{ER} \beta$}

To determine which region of the hUcn promoter is responsible for the inhibition of transcriptional activity induced by $\mathrm{E}_{2}$ via $\mathrm{ER} \beta$ (Fig. $1 A, B$ ), PC12 cells were cotransfected with ER $\beta$ and the different deletion mutants of the hUcn promoter. These cells were then treated with $\mathrm{E}_{2}$. As illustrated in Figure $5 \mathrm{~A}$, the activity of the pGL2-hUS2, $\Delta-349 /-161,-427,-349$, and -161 promoters was significantly decreased after $\mathrm{E}_{2}$ treatment (Fig. $5 A$ ). The response to $\mathrm{E}_{2}$ by the -161 promoter, which contains the CRE
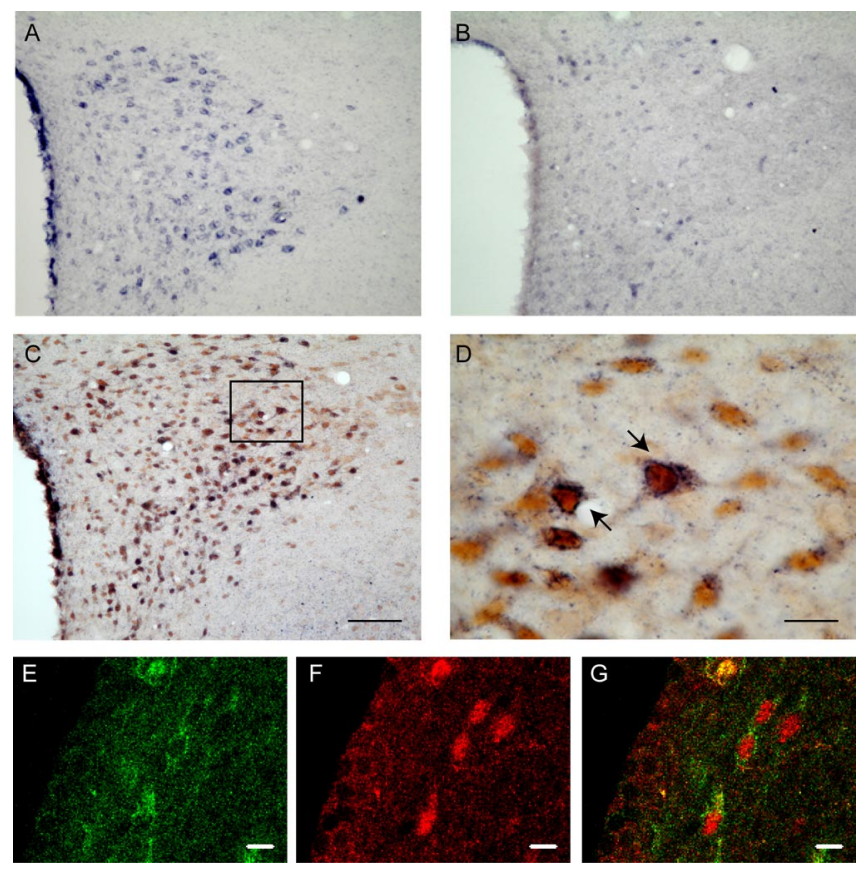

Figure 6. Ucn coexists with $E R \beta$ in cells of the rat PVN and with $E R \alpha$ in the periventricular nucleus of the hypothalamus. $\boldsymbol{A}$, ISH for Ucn mRNA (dark blue staining) in a coronal tissue section at the level of the PVN in the presence of the U2 probe. $\boldsymbol{B}$, Negative ISH control at the same level of the PVN using a scramble probe shows background staining. $C, D$, Coexistence of Ucn mRNA with ER $\beta$ immunoreactivity (brown staining). $\boldsymbol{D}$, Higher magnification of the frame depicted in $\boldsymbol{C}$. Confocal immunofluorescence detection of $\operatorname{Ucn}(\boldsymbol{E}$, green) and $\operatorname{ER} \alpha(\boldsymbol{F}$, red) in the periventricular nucleus of the hypothalamus is shown. $\boldsymbol{G}$, Merge of $\boldsymbol{E}$ and $\boldsymbol{F}$. Scale bars: $\boldsymbol{D}-\boldsymbol{G}, 10$ $\mu \mathrm{m}$; (in C) A-C, $100 \mu \mathrm{m}$.

site, was similar to the pGL2-hUS2 (Fig. 5A). In addition, the $\Delta-161 /-41$ promoter not containing the CRE site was not affected by $\mathrm{E}_{2}$ treatment (Fig. $5 A$ ), suggesting that the CRE site is involved in the repression of hUcn promoter activity exerted by $\mathrm{E}_{2}-\mathrm{ER} \beta$.

To further study the mechanism involved in the observed repression of the hUcn promoter transcriptional activity by $\mathrm{E}_{2}$ $\mathrm{ER} \beta, \mathrm{PC} 12$ cells were cotransfected with $\mathrm{ER} \beta$ and the -161 promoter. The PC12 cells were then treated with 8 -Br-cAMP (0.5 $\mathrm{mm}$ ) to stimulate the protein kinase A-CRE pathway, with or without $\mathrm{E}_{2}$. As shown in Figure $5 \mathrm{~B}$, treatment of PC12 cells overexpressing ER $\beta$ with 8-Br-cAMP significantly increased the activity of the -161 promoter. Treatment with $\mathrm{E}_{2}$ in the presence of 8-Br-cAMP significantly decreased the transcriptional activity of the -161 promoter (Fig. $5 B$ ).

\section{Ucn coexists with ERs in hypothalamic neurons}

The nonisotopic ISH protocol used herein confirmed the previously reported pattern of cells expressing Ucn mRNA in the brain of female and male rats (Kozicz et al., 1998, Bittencourt et al., 1999; Gysling et al., 2004; Haeger et al., 2005). Numerous cells expressing Ucn mRNA were observed in the PVN (Fig. 6A) of both male and female rats. ISH with a scrambled probe showed only background staining (Fig. 6B). To study whether $U c n$ mRNA coexists with $\mathrm{ER} \beta$ in the same cells of the PVN, a double ISH/IHC protocol using a DIG-labeled probe for Ucn mRNA (U2) and an specific ER $\beta$ antibody was performed. Positive ER $\beta$ like staining was observed in parvicellular (Fig. 6C) and magnocellular (data not shown) neurons of the PVN. As illustrated in Figure 6, $C$ and $D$, several cells in the parvicellular region of the PVN coexpress Ucn mRNA and ER $\beta$. The $39.0 \pm 6.1 \%$ of positive ER $\beta$-like cells coexpress Ucn mRNA (total ER $\beta$-like labeling 


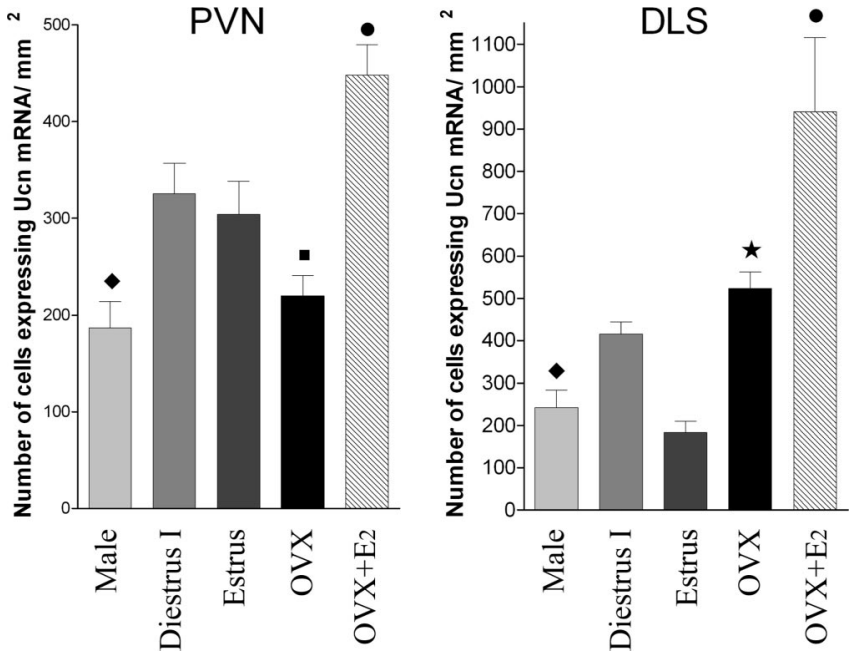

Figure 7. In situ expression of Uen mRNA in different endocrine status in the PVN and DLS of the rat brain. Coronal tissue sections were processed for ISH using the U1 DIG-labeled probe. Values correspond to the mean \pm SEM of three to seven independent experiments. Analysis by one-way ANOVA showed a significant difference between experimental conditions in both areas studied (PVN: $F=14.17, R^{2}=0.76, p<0.0001$; DLS: $F=8.65, R^{2}=0.60, p<$ $0.0002)$. Newman-Keuls multiple comparison post hoc test gave the following significances: PVN,,$p<0.05$ compared with estrus, $p<0.01$ compared with diestrus I, and $p<0.001$ compared with male and OVX, $\diamond, p<0.05$ compared with diestrus I and estrus, $\mathbf{\square}, p<0.05$ compared with diestrus I and estrus; DLS, $\bullet, p<0.001$ compared with diestrus I, and OVX, $p<0.01$ compared with diestrus I, estrus, and OVX, and $p<0.001$ compared with male, $\star, p<0.05$ compared with diestrus I and $p<0.01$ compared with $0 \mathrm{VX}$.

in the whole parvicellular region of the PVN was $205 \pm 29$ cells; $n=4)$. We also performed a double immunofluorescent protocol with $U \mathrm{cn}$ and ER $\alpha$ antibody in colchicine-treated rats. Significant double cytoplasmatic Ucn-like and nuclear ER $\alpha$-like labeling was observed in the periventricular region of the hypothalamus (Fig. 6E-G).

\section{In situ expression of Ucn mRNA in the PVN and DLS of female and male rats}

The results with PC12 cells prompted us to study whether changes in the level of ovarian hormones affected the expression of Ucn mRNA in the PVN (the main hypothalamic nucleus related to stress) and in the DLS (an extra hypothalamic nucleus related to stress) (Sheehan et al., 2004). For this purpose, ISH of $\mathrm{Ucn}$ mRNA was performed in male and female rats in two different stages of the estrous cycle (diestrus I and estrus). This was also done in $30 \mathrm{~d}$ OVX rats after a single injection of $\mathrm{E}_{2}$ or vehicle $28 \mathrm{~h}$ before ISH. For this part of the study, the U1 probe was used. This probe gave the same labeling pattern as the U2 probe, used for the double ISH/IHC protocol. The fact that similar labeling was observed with two different probes confirms the specificity of the label. In the PVN, male rats had a significantly lower number of cells expressing Ucn mRNA than female rats in diestrus I and estrus (Fig. 7). There was no significant difference in the number of cell expressing Ucn mRNA in the PVN between males and $30 \mathrm{~d}$ OVX rats (Fig. 7). The number of cells expressing Ucn mRNA in the PVN of diestrus I and estrus rats was not significantly different (Fig. 7). In addition, no significant difference was observed in the PVN between $30 \mathrm{~d}$ OVX rats with and without vehicle administration $(220.0 \pm 20.8, n=5$ vs $213.8 \pm 19.8, n=3 ; p>0.05)$. The number of cells expressing Ucn mRNA in the PVN of $30 \mathrm{~d}$ OVX rats was significantly lower compared with female rats in diestrus I and estrus (Fig. 7). A significant increase in the number of cells expressing Ucn mRNA was observed in the $30 \mathrm{~d}$ OVX rats treated with a single $\mathrm{E}_{2}$ injection $28 \mathrm{~h}$ before ISH. In fact, the number of Ucn mRNA-expressing cells in the PVN of $E_{2}$-treated OVX rats was significantly higher than male and female rats in diestrus I and estrus.

In the case of the DLS, male rats had a significantly lower number of cells expressing Ucn mRNA than female rats during diestrus I and $30 \mathrm{~d}$ OVX rats (Fig. 7). The number of cells expressing Ucn mRNA in the DLS during estrus was significantly lower than rats in diestrus I and $30 \mathrm{~d}$ OVX rats (Fig. 7). Thus, there is a significant difference between male and $30 \mathrm{~d}$ OVX rats in the DLS, but not in the PVN. As in the PVN, there was no significant difference observed in the DLS between $30 \mathrm{~d}$ OVX rats with and without vehicle administration ( $523.5 \pm 39.3, n=7$ vs $488.1 \pm$ $56.7, n=4)$. There was also a significant increase in the number of cells expressing Ucn mRNA in the $30 \mathrm{~d}$ OVX rats $28 \mathrm{~h}$ after a single $\mathrm{E}_{2}$ injection. The number of $\mathrm{Ucn} \mathrm{mRNA}$ expressing-cells in the DLS of $\mathrm{E}_{2}$-treated OVX rats was significantly higher than female rats in diestrus I and estrus.

\section{Discussion}

The results of our current investigation indicate that estrogens differentially regulate the expression of the mammalian Ucn gene depending on the estrogen receptor involved. First, transient cotransfection studies allowed us to demonstrate that $\mathrm{E}_{2}$ exerts a direct effect on the transcriptional activity of the hUcn promoter. Estrogens increase the transcriptional activity of the hUcn promoter through $\mathrm{ER} \alpha$, whereas they decrease it through ER $\beta$. Second, estrogen receptors coexist with $U \mathrm{cn}$ in neurons of the rat hypothalamus, giving anatomical support for a direct effect of estrogen receptors on the Ucn gene. Third, we have shown significant differences in the number of cells expressing Ucn mRNA in the DLS and the PVN between male and female rats in different ovarian hormonal states, supporting the transfection studies. Thus, our in vitro and in vivo evidence suggests that estrogens exert a direct and differential transcriptional regulation of the Ucn gene.

Analysis of mouse, rat, and human Ucn promoters showed that the $1 \mathrm{~kb}$ proximal region of the human promoter shares 42 and $38 \%$ homology with rat and mouse promoters, respectively. The three promoters analyzed have several conserved half-EREs and other sites that have been shown to work in conjunction with half-EREs, such as Ap1 (Petz et al., 2002) and Sp1 (Sanchez et al., 2002; Petz et al., 2004), substantiating a direct regulation of the $\mathrm{Ucn}$ gene by estrogens. We observed that $\mathrm{E}_{2}$ and tamoxifen consistently increase the hUcn promoter activity in PC12 cells cotransfected with ER $\alpha$ in a dose-dependent manner. We demonstrated that this response to $\mathrm{E}_{2}$ and tamoxifen requires the region of the hUcn promoter upstream and downstream of position349 , containing both half-ERE and Sp1, and/or Ap1 sites. It has been established that the coordinated activity of half-ERE and Sp1 sites regulate the expression of several estrogen-inducible human genes (reviewed by Sanchez et al., 2002). The mechanism proposed for this coordinated $\mathrm{ER} \alpha$ and $\mathrm{Sp} 1$ transactivation implies increased Sp1 binding induced by the binding of $\operatorname{ER} \alpha$ to a half-ERE, and a direct interaction between these two transcription factors (Porter et al., 1997; Petz and Nardulli, 2000; Kim et al., 2003; Petz et al., 2004). Our data with the deleted mutants of the hUcn promoter and EMSA suggest that the half-ERE and the $\mathrm{Sp} 1$ sites contribute to the $\mathrm{E}_{2}$-induced transactivation of the hUcn promoter mediated by $\operatorname{ER} \alpha$. Additional studies with point mutations of these elements should test this hypothesis as well as 
the possible involvement of the Ap1 site present in the same promoter region.

In contrast to the increase in activity of the hUcn promoter exerted by $\mathrm{E}_{2}-\mathrm{ER} \alpha, \mathrm{E}_{2}$ treatment of PC12 cells expressing ER $\beta$ decreases the activity of the hUcn promoter. The study with deleted mutants of the hUcn promoter demonstrated that the region containing a CRE site is responsible for the repression exerted by $\mathrm{E}_{2}-\mathrm{ER} \beta$. Zhao et al. (1998) postulated that this CRE site is involved in the basal activity of the hUcn promoter. Our results further confirm the importance of this CRE site. Furthermore, $\mathrm{E}_{2}$-ER $\beta$ significantly decreases $U \mathrm{cn}$ promoter activity even in the presence of 8-Br-cAMP. It has been shown that ERs regulate the transcriptional activity of other genes through two CREdependent mechanisms. First, E2-ER $\beta$ decreases cyclinD gene expression by binding to a CRE element in the cyclinD promoter (Liu et al., 2002). Second, E2-ER $\beta$ competes with CRE-binding proteins in the tyrosine hydroxylase promoter (Maharjan et al., 2005).

Tamoxifen has antiestrogenic or estrogenic effects, depending on the cellular context (Kim et al., 2003). We observed that tamoxifen significantly increases hUcn promoter activity mediated by $\operatorname{ER} \alpha$ but not by ER $\beta$. Tamoxifen has been proposed to have effects on mood. For instance, chronic administration of tamoxifen to ovariectomized monkeys resulted in increased anxiety (Mook et al., 2005). It has also been shown to have an antimanic effect when administered to bipolar patients (Bebchuk et al., 2000). It would be of interest to explore whether the observed increase in Ucn expression induced by tamoxifen is involved in these mood-related effects.

Gender differences in the HPA axis response to stress have been observed in CRH-KOs (Muglia et al. 1995). In addition, the expression of $\mathrm{Ucn}$ in the PVN has been reported (Kozicz et al., 1998). Together with our evidence that estrogens exert a direct transcriptional regulation of the $U \mathrm{cn}$ gene raises the possibility that $U \mathrm{cn}$ is responsible at least in part for the gender differences observed in CRH-KOs. This is further supported by our anatomical evidence showing the coexistence of $U c n$ mRNA and ER $\beta$ in the same PVN cells. We were not able to obtain consistent results regarding the presence of $\mathrm{ER} \alpha$ in the $\mathrm{PVN}$; however, the presence of ER $\alpha$ in the PVN has been documented in rats (Suzuki and Handa, 2005) and humans (Bao et al. 2005). Additional studies would be appropriate to address whether $U \mathrm{cn}$ and $\mathrm{ER} \alpha$ coexist in the same PVN neurons. Prior studies have established the expression of $\operatorname{ER} \alpha$ (Laflamme et al., 1998) in the periventricular hypothalamic nucleus. In our study, we observed coexpression of ER $\alpha$ and $U c n$ in periventricular hypothalamic neurons, giving anatomical support for $\mathrm{E}_{2}$-ER $\alpha$ mediated regulation of $\mathrm{Ucn}$ expression in this nucleus.

To obtain evidence that estrogens regulate the Ucn transcription in vivo we studied the in situ expression of Ucn mRNA in the PVN and the DLS of cycling and OVX female rats, as well as male rats. The results showed significant differences in the number of neurons expressing Ucn mRNA in both nuclei, and between male and female rats in different hormonal states. Furthermore, acute $\mathrm{E}_{2}$ administration to OVX rats significantly increased Ucn mRNA in both nuclei, suggesting that estrogens regulate the Ucn transcription in vivo. Different levels of ERs and $\mathrm{E}_{2}$ could explain the observed changes in Ucn mRNA, as different expression patterns for $\operatorname{ER} \alpha$ and $\operatorname{ER} \beta$ have been shown in the mammalian brain. The PVN mainly expresses ER $\beta$ (Shughrue et al., 1997; Laflamme et al., 1998), the expression of which is decreased in $\mathrm{E}_{2}$-treated OVX rats (Shima et al., 2003; Suzuki and Handa 2004). In contrast, the DLS mainly expresses ER $\alpha$ (Shughrue et al., 1997, Laflamme et al., 1998). Available evidence indicates that the brain expression of both ERs mRNA changes during the estrous cycle and/or under different endocrine conditions in a temporal and regionspecific manner (Shughrue et al., 1992; Greco et al., 2003). Changes in the expression of ERs or in the ratio $\mathrm{ER} \alpha / \mathrm{ER} \beta$ could underlie the observed changes in Ucn mRNA expression in the different brain regions and hormonal states studied. It is not possible, however, to rule out the role that other gonadal hormones aside from estrogens can have on the observed changes in Ucn expression.

The Edinger-Westphal nucleus (EW) is the major site of $\mathrm{Ucn}$ expression in the brain (Kozicz et al., 1998). Mitra et al. (2003) reported labeling for $\mathrm{ER} \beta$ in mouse $\mathrm{EW}$; however, we were not able to detect ER $\beta$ labeling in this nucleus. Additional studies should test whether estrogens regulate the expression of Ucn in EW. The PVN and the DLS express lower levels of Ucn than EW. Controversy over this matter has emerged: Kozicz et al. (1998) showed the presence of numerous cells expressing Ucn-like immunoreactivity in the PVN of colchicine-treated rats and scattered cells in the septum. In contrast, Bittencourt et al. (1999) did not observe Ucn labeling in the PVN under similar methodological conditions. Furthermore, Ucn mRNA in the PVN was observed only in colchicine-treated rats. Our ISH protocol allowed us to demonstrate the presence of Ucn mRNA in the PVN and the DLS of noncolchicine-treated rats. Part of this controversy may be because of subtle methodological differences, such as the type and speed of fixation, which are crucial for protein and mRNA preservation (Chu et al., 2005). In addition, the apparent weak Ucn expression in the PVN and other brain regions expressing $\mathrm{Ucn}$ mRNA may be because of rapid $U \mathrm{cn}$ transport to nerve terminals. Moreover, even a weak Ucn expression in the PVN and the DLS may be functionally relevant because of the higher affinity of $U \mathrm{cn}$ for both $\mathrm{CRH}$ receptors, rather than $\mathrm{CRH}$ itself (Vaughan et al., 1995; Bale and Vale, 2004).

In summary, our heterologous transfection and anatomical studies demonstrate that estrogens exert differential effects on Ucn gene expression in different cellular contexts and endocrine states. Additional in vivo studies with chromatin immunoprecipitation will assist in determining whether the estrogen effects observed in vivo are caused by the formation of a transcriptional complex on the Ucn promoter, in its natural chromatin context in different target tissues. Estrogens also differentially regulate stress-related genes such as vasopressin (Shapiro et al., 2000), CRH (Vamvakopoulos and Chrousos, 1993; Ni et al., 2004; Miller et al., 2004), CRH binding protein (Van de Stolpe et al., 2004), and tyrosine hydroxylase (Maharjan et al., 2005). Estrogen receptors differentially regulate the expression of $U \mathrm{cn}$ and $\mathrm{CRH}$ in brain regions involved in the stress response based on gender. Therefore, it would be of interest to study how the changes in $\mathrm{Ucn} / \mathrm{CRH}$ balance induced by estrogens affect the physiologic and pathologic responses to stress.

\section{References}

Andres ME, Gysling K, Araneda S, Venegas A, Bustos G (1996) NMDA-NR1 receptor subunit mRNA expression in rat brain after 6-OH-dopamine induced lesions: a nonisotopic in situ hybridization study. J Neurosci Res 46:375-384.

Bale TL, Vale WW (2004) CRF and CRF receptors: role in stress responsivity and other behaviors. Annu Rev Pharmacol Toxicol 44:525-557.

Bao AM, Hestiantoro A, Van Someren EJ, Swaab DF, Zhou JN (2005) Colocalization of corticotropin-releasing hormone and oestrogen receptoralpha in the paraventricular nucleus of the hypothalamus in mood disorders. Brain 128:1301-1313.

Bebchuk JM, Arfken CL, Dolan-Manji S, Murphy J, Hasanat K, Manji HK 
(2000) A preliminary investigation of a protein kinase $\mathrm{C}$ inhibitor in the treatment of acute mania. Arch Gen Psychiatry 57:95-97.

Bittencourt JC, Vaughan J, Arias C, Rissman RA, Vale WW, Sawchenko PE (1999) Urocortin expression in rat brain: evidence against a pervasive relationship of urocortin-containing projections with targets bearing type 2 CRF receptors. J Comp Neurol 415:285-312.

Chu WS, Furusato B, Wong K, Sesterhenn IA, Mostofi FK, Wei MQ, Zhu Z, Abbondanzo SL, Liang Q (2005) Ultrasound-accelerated formalin fixation of tissue improves morphology, antigen and mRNA preservation. Mod Pathol 18:850-863.

Donaldson CJ, Sutton SW, Perrin MH, Corrigan AZ, Lewis KA, Rivier JE, Vaughan JM, Vale WW (1996) Cloning and characterization of human urocortin. Endrocrinology 137:2167-2170.

Dunn AJ, Swiergiel AH (1999) Behavioral responses to stress are intact in CRF-deficient mice. Brain Res 845:14-20.

Greco B, Lubbers LS, Blaustein JD (2003) Estrogen receptor beta messenger ribonucleic acid expression in the forebrain of proestrous, pregnant, and lactating female rats. Endocrinology 144:1869-1875.

Gysling K, Forray MI, Haeger P, Daza C, Rojas R (2004) Corticotropinreleasing hormone and urocortin: redundant or distinctive functions? Brain Res Rev 47:116-125.

Haeger P, Cuevas R, Forray MI, Rojas R, Daza C, Rivadeneira J, Gysling K (2005) Natural expression of immature Ucn antisense RNA in the rat brain. Evidence favoring bidirectional transcription of the Ucn gene locus. Brain Res Mol Brain Res 139:115-128.

Hall JM, Couse JF, Korach KS (2001) The multifaceted mechanisms of estradiol and estrogen receptor signaling. J Biol Chem 276:36869-36872.

Jones P, Parrott E, White NH (1999) Activation of transcription by estrogen receptor $\alpha$ and beta is cell type and promoter dependent. J Biol Chem 274:32008-32014.

Kim K, Thu N, Saville B, Safe S (2003) Domains of estrogen receptor alpha (ERalpha) required for ERalpha/Sp1-mediated activation of GC-rich promoters by estrogens and antiestrogens in breast cancer cells. Mol Endocrinol 17:804-817.

Kozicz T, Yanaihara H, Arimura A (1998) Distribution of urocortin-like immunoreactivity in the central nervous system of the rat. J Comp Neurol 391:1-10.

Laflamme N, Nappi RE, Drolet G, Labrie C, Rivest S (1998) Expression and neuropeptidergic characterization of estrogen receptors (ERalpha and ERbeta) throughout the rat brain: anatomical evidence of distinct roles of each subtype. J Neurobiol 36:357-378.

Liu MM, Albanese C, Anderson CM, Hilty K, Webb P, Uht RM, Price Jr RH, Pestell RG, Kushner PJ (2002) Opposing action of estrogen receptors alpha and beta on cyclin D1 gene expression. J Biol Chem 277:24353-24360.

Maharjan S, Serova L, Sabban EL (2005) Transcriptional regulation of tyrosine hydroxylase by estrogen: opposite effects with estrogen receptors alpha and beta and interactions with cyclic AMP. J Neurochem 93:1502-1514.

Martini PG, Katzenellenbogen BS (2001) Regulation of prothymosin alpha gene expression by estrogen in estrogen receptor-containing breast cancer cells via upstream half-palindromic estrogen response element motifs. Endocrinology 142:3493-3501.

Miller WJ, Suzuki S, Miller LK, Handa R, Uht RM (2004) Estrogen receptor (ER) $\beta$ isoforms rather than $\mathrm{ER} \alpha$ regulate corticotropin-releasing hormone promoter activity through an alternate pathway. J Neurosci 24:10628-10635.

Mitra SW, Hoskin E, Yudkovitz J, Pear L, Wilkinson HA, Hayashi S, Pfaff DW, Ogawa S, Rohrer SP, Schaeffer JM, McEwen BS, Alves SE (2003) Immunolocalization of estrogen receptor beta in the mouse brain: comparison with estrogen receptor alpha. Endocrinology 144:2055-2067.

Mook D, Felger J, Graves F, Wallen K, Wilson ME (2005) Tamoxifen fails to affect central serotonergic tone but increases indices of anxiety in female rhesus macaques. Psychoneuroendocrinology 30:273-283.

Muglia L, Jacobson L, Dikkes P, Majzoub JA (1995) Corticotropin-releasing hormone deficiency reveals major fetal but not adult glucocorticoid need. Nature 373:427-432.

Muglia LJ, Jacobson L, Weninger SC, Karalis KP, Jeong K, Majzoub JA (2001) The physiology of corticotropin-releasing hormone deficiency in mice. Peptides 22:725-731.

Ni X, Hou Y, King BR, Tang X, Read MA, Smith R, Nicholson RC (2004)
Estrogen receptor-mediated down-regulation of corticotropin-releasing hormone gene expression is dependent on a cyclic adenosine $3^{\prime}, 5^{\prime}$ monophosphate regulatory element in human placental syncytiotrophoblast cells. J Clin Endocrinol Metab 89:2312-2318.

Paxinos G, Watson C (1986) The rat brain in stereotaxic coordinates, Ed 2. Sydney: Academic.

Petz LN, Nardulli AM (2000) Spl binding sites and an estrogen response element half-site are involved in regulation of the human progesterone receptor A promoter. Mol Endocrinol 14:972-985.

Petz LN, Ziegler YS, Loven MA, Nardulli AM (2002) Estrogen receptor alpha and activating protein-1 mediate estrogen responsiveness of the progesterone receptor gene in MCF-7 breast cancer cells. Endocrinology 143:4583-4591.

Petz LN, Ziegler YS, Schultz JR, Kim H, Kemper JK, Nardulli AM (2004) Differential regulation of the human progesterone receptor gene through an estrogen response element half site and Sp1 sites. J Steroid Biochem Mol Biol 8:113-122.

Porter W, Saville B, Hoivik D, Safe S (1997) Functional synergy between the transcription factor Sp1 and the estrogen receptor. Mol Endocrinol 11:1569-1580.

Sabbah M, Courilleau D, Mester J, Redeuilh G (1999) Estrogen induction of the cyclin D1 promoter: involvement of a cAMP response-like element. Proc Natl Acad Sci USA 96:11217-11222.

Sanchez R, Nguyen D, Rocha W, White JH, Mader S (2002) Diversity in the mechanisms of gene regulation by estrogen receptors. Bioessays 24:244-254.

Schultz JR, Petz LN, Nardulli AM (2005) Cell- and ligand-specific regulation of promoters containing activator protein-1 and $\mathrm{Sp} 1$ sites by estrogen receptors alpha and beta. J Biol Chem 280:347-354.

Shapiro RA, Xu C, Dorsa DM (2000) Differential transcription regulation of rat vasopressin gene expression by estrogen receptor $\alpha$ and $\beta$. Endocrinology 141:4056-4064.

Sheehan TP, Chambers RA, Russell DS (2004) Regulation of affect by the lateral septum: implications for neuropsychiatry. Brain Res Rev 46:71-117.

Shima N, Yamaguchi Y, Yuri K (2003) Distribution of estrogen receptor beta mRNA-containing cells in ovariectomized and estrogen-treated female rat brain. Anat Sci Int 78:85-97.

Shughrue PJ, Bushnell CD, Dorsa DM (1992) Estrogen receptor messenger ribonucleic acid in female rat brain during the estrous cycle: a comparison with ovariectomized females and intact males. Endocrinology 131:381-388.

Shughrue PJ, Lane MV, Merchenthaler I (1997) Comparative distribution of estrogen receptor-alpha and -beta mRNA in the rat central nervous system. J Comp Neurol 388:507-525.

Suzuki S, Handa RJ (2004) Regulation of estrogen receptor-beta expression in the female rat hypothalamus: differential effects of dexamethasone and estradiol. Endocrinology 145:3658-3670.

Suzuki S, Handa RJ (2005) Estrogen receptor-beta, but not estrogen receptor-alpha, is expressed in prolactin neurons of the female rat paraventricular and supraoptic nuclei: Comparison with other neuropeptides. J Comp Neurol 484:28-42.

Vamvakopoulos NC, Chrousos GP (1993) Evidence of direct estrogenic regulation of human corticotropin-releasing hormone gene expression. Potential implications for the sexual dimorphism of the stress response and immune/inflammatory reaction. J Clin Invest 92:1896-1902.

Van de Stolpe A, Slycke AJ, Reinders MO, Zomer AW, Goodenough S, Behl C, Seasholtz AF, van der Saag PT (2004) Estrogen receptor (ER)-mediated transcriptional regulation of the human corticotropin-releasing hormone-binding protein promoter: differential effects of ERalpha and ERbeta. Mol Endocrinol 18:2908-2923.

Vaughan J, Donaldson C, Bittencourt J, Perrin MH, Lewis K, Sutton S, Chan R, Turnbull AV, Lovejoy D, Rivier C, Rivier J, Sawchenko PE, Vale W (1995) Urocortin, a mammalian neuropeptide related to fish urotensin I and to corticotropin-releasing factor. Nature 378:287-292.

Weninger SC, Dunn AJ, Muglia LJ, Dikkes P, Miczek KA, Swiergiel AH, Berridge CW, Majzoub JA (1999) Stress-induced behaviors require the corticotropin-releasing hormone $(\mathrm{CRH})$ receptor, but not CRH. Proc Natl Acad Sci USA 96:8283-8288.

Zhao L, Donaldson CJ, Smith GW, Vale WW (1998) The structures of the mouse and human urocortin genes (Ucn and UCN). Genomics 50:23-33. 